\title{
Status Nutrisi sebagai Faktor Risiko Sindrom Syok Dengue
}

Sarah Buntubatu, Eggi Arguni, Ratni Indrawanti, Ida Safitri Laksono, Endy P. Prawirohartono

Departemen Ilmu Kesehatan Anak Fakultas Kedokteran Universitas Gadjah Mada/RSUP Dr. Sardjito, Yogyakarta

Latar belakang. Risiko kematian pada anak dengan sindrom syok dengue (SSD) tinggi. Obesitas diduga sebagai faktor risiko SSD tetapi hasil penelitian sebelumnya masih kontroversial.

Tujuan. Mengevaluasi overweight atau obes sebagai faktor risiko SSD pada anak.

Metode. Penelitian case control pada anak (0-18 tahun) yang dirawat di RSUP Dr. Sardjito Yogyakarta dari bulan April 2012 sampai Maret 2015 dengan infeksi dengue, yang ditegakkan berdasarkan kriteria WHO 2011 dan hasil uji serologi darah atau NS1. Analisis statistik dikerjakan dengan analisis multivariat dan stratifikasi. Kemaknaan faktor risiko dilaporkan sebagai odds ratio (OR) dengan interval kepercayaan $95 \%$.

Hasil. Dilaporkan 264 anak terdiri dari 88 kasus (SSD) dan 176 kontrol (non SSD) diikutkan dalam penelitian ini. Anak dengan overweight atau obesitas mempunyai risiko SSD 2,29 kali dibanding bukan overweight atau obes $(\mathrm{OR}=2,29 ; \mathrm{IK} 95 \%: 1,24-4,22)$ dan perempuan mempunyai risiko SSD 1,84 kali lebih tinggi dibanding laki-laki (OR=1,84; IK95\%:1,08-3,14). Jumlah trombosit merupakan modifier, yaitu anak overweight atau obes dengan angka trombosit $<20.000 / \mu \mathrm{L}$ mempunyai risiko 3,26 kali dibanding anak dengan SSD dengan overweight atau obes dengan angka trombosit $\geq 20.000 / \mu \mathrm{L}(\mathrm{OR}=3,26 ; \mathrm{IK} 95 \%: 1,22-8,72)$.

Kesimpulan. Overweight atau obes dan jenis kelamin perempuan merupakan faktor risiko untuk SSD dan jumlah trombosit $<20.000 / \mu \mathrm{L}$ merupakan modifier. Sari Pediatri 2016;18(3):226-32

Kata kunci: sindrom syok dengue, faktor risiko, overweight, obesitas, perempuan

\section{Nutritional Status as A Risk Factor for Dengue Shock Syndrome}

Sarah Buntubatu, Eggi Arguni, Ratni Indrawanti, Ida Safitri Laksono, Endy P. Prawirohartono

Background. Children with dengue shock syndrome (DSS) are at high risk for death. Obesity has long been considered as a risk factor for DSS. However, a number of studies found controversial results.

Objective. To evaluate overweight or obese as a risk factor for DSS in children.

Methods. We conducted a case control study in children (0-18 years old) who were admitted to Dr. Sardjito Hospital, Yogyakarta from April 2012 to March 2015 with dengue infection, which was confirmed by the 2011 WHO dengue clasification and the results of blood anti dengue serology or NS1. Statistical analysis was performed with multivariate analysis and stratification. The risk factor is presensted as odds ratio (OR) with 95\% confidence interval (95\% CI).

Results. We included in the analysis 264 children, consisting of 88 cases (DSS) and 176 controls (non DSS). Overweight or obese children had a higher risk for DSS than those with normal nutritional status (OR=2.29; 95\% CI 1.24 to 4.22), and girls had higher risk of DSS than boys $(\mathrm{OR}=1.84 ; 95 \% \mathrm{CI} 1.08$ to 3.14). We identified that platelet count was a modifier, in which overweight or obese children with platelet count $<20,000 / \mu \mathrm{L}$ had higher risk for DSS (OR=3.26 95\% CI 1.22 to 8.72) compared to overweight or obese children with platelet count $\geq 20,000 / \mu \mathrm{L}$.

Conclusions. Overweight or obese and girl are risk factors for DSS, whereas platelet count $<20,000 / \mu \mathrm{L}$ is a modifier. Sari Pediatri 2016;18(3):226-32

Keyword: dengue shock syndrome, risk factor, overweight, obesity, girls

Alamat korespondensi: Dr. Sarah Buntubatu. Peserta Program Pendidikan Dokter Spesialis Ilmu Kesehatan Anak, Departemen Ilmu Kesehatan Anak FK UGM-RSUP Dr. Sardjito. E-mail: sarahjuly2012@yahoo.com 
$\mathrm{P}$ revalensi demam berdarah dengue (DBD) di seluruh dunia telah meningkat 30 kali lipat dalam 50 tahun terakhir. Indonesia merupakan daerah endemis infeksi dengue dengan jumlah kasus DBD terbesar di dunia sejak tahun 2007. Pada tahun 2013 di Daerah Istimewa Yogyakarta terdapat 96 kasus per 100.000 penduduk dengan case fatality rate $0,48 \%{ }^{1,2}$

Virus dengue dapat menyebabkan manifestasi klinis yang bervariasi, dari asimtomatik sampai DBD dengan perembesan plasma, yang dapat mengakibatkan sindrom syok dengue (SSD). Penyakit DBD mempunyai kemungkinan 5\% menyebabkan kematian, tetapi jika berkembang menjadi SSD angka kematian meningkat menjadi 40\%-50\%. ${ }^{3,4}$

Status nutrisi memengaruhi derajat penyakit berdasarkan teori imunologi, yaitu gizi baik meningkatkan respon antibodi. Reaksi antigen dan antibodi yang berlebihan menyebabkan infeksi dengue lebih berat. Walaupun demikian, mekanisme peningkatan SSD pada obesitas masih belum jelas. Hal ini mungkin berhubungan dengan pelepasan sitokin pro-inflamasi oleh sel adiposit jaringan lemak. Sel adiposit jaringan lemak mensekresikan dan melepaskan sitokin proinflamasi yaitu tumour necrosis factor $\alpha(\mathrm{TNF} \alpha)$ dan beberapa interleukin (IL) yaitu IL-1 $\beta$, IL-6, dan IL-8. Pada obesitas terjadi peningkatan ekspresi TNF $\alpha$ dan IL-6. Salah satu dampak TNF $\alpha$ adalah meningkatkan permeabilitas kapiler, sedangkan pada SSD juga terjadi produksi TNF $\alpha$, IL-1, IL-6 dan IL-8. ${ }^{5-7}$ Beberapa penelitian sebelumnya mengenai hubungan status nutrisi dengan derajat infeksi dengue memberikan hasil yang bervariasi. ${ }^{8-13}$

\section{Metode}

Penelitian retrospektif case control dengan pengambilan data dari rekam medis pasien yang dirawat inap di RSUP Dr. Sardjito, Yogyakarta mulai April 2012 sampai dengan Maret 2015 berumur 0-18 tahun yang dipilih secara consecutive sampling. Kelompok kontrol adalah anak dengan DBD derajat I dan II (non syok). Kasus adalah pasien SSD dengan kriteria inklusi pasien DBD atau SSD sesuai kriteria WHO $2011^{14}$ yang dikonfirmasi dengan pemeriksaan serologi (IgM dan IgG anti-dengue) atau pemeriksaan rapid test antigen virus (NS1). Kriteria eksklusi adalah catatan medis pasien tidak lengkap. Besar sampel dihitung berdasarkan rumus untuk penelitian case control tidak berpasangan, dengan asumsi kesalahan tipe 1 sebesar $5 \%$, power penelitian 0,8 , dan prevalensi 0,21 maka besar sampel penelitian ini adalah 264 yang terdiri dari 88 kasus dan 176 kontrol. ${ }^{15}$

Status nutrisi dinilai berdasarkan berat badan menurut panjang/tinggi badan $(\mathrm{BB} / \mathrm{PB}$ atau $\mathrm{BB} /$ TB) untuk usia $<5$ tahun atau BMI $\left(\mathrm{kg} / \mathrm{m}^{2}\right)$ menurut usia $\geq 5$ tahun berdasarkan WHO Growth Standard 2007, dengan kategori gizi buruk $(<-3 S D)$, gizi kurang $(-3 \leq z<-2 S D)$, gizi baik $(-2 \leq z \leq 2 S D)$, gizi lebih $(2<\mathrm{z} \leq 3 \mathrm{SD}$ untuk $\mathrm{BB} / \mathrm{PB}$ atau $\mathrm{BB} / \mathrm{TB} ; 1<\mathrm{z} \leq 2$ untuk $\mathrm{BMI} / \mathrm{U}$ ), obesitas ( $>3 \mathrm{SD}$ untuk $\mathrm{BB} / \mathrm{PB}$ atau $\mathrm{BB} /$ $\mathrm{TB}$; >2SD untuk BMI/U). ${ }^{16,17}$ Status nutrisi dibagi menjadi 2 kelompok, status nutrisi overweight dan obes dimasukkan dalam kelompok berisiko, status nutrisi normal dan malnutrisi dalam kelompok tidak berisiko.

Faktor risiko ditentukan dengan analisis bivariat menggunakan status nutrisi sebagai variabel bebas, derajat dengue sebagai variabel tergantung, jenis kelamin, usia sebagai confounder. Variabel bebas dan confounder yang mempunyai nilai $\mathrm{p}<0,2$ dari analisis bivariat dimasukkan ke dalam model multivariat dengan analisis logistik regresi. Hemokonsentrasi, jumlah trombosit, status imun anti-dengue sebagai modifier dianalisis secara stratifikasi. Kemaknaan ditentukan dengan odds ratio (OR) dan angka kepercayaan 95\% (IK95\%). Penelitian ini mendapat persetujuan dari Komisi Etik Fakultas Kedokteran Universitas Gadjah Mada dan RSUP Dr. Sardjito, Yogyakarta.

\section{Hasil}

Berdasarkan data rekam medis April 2012 - Maret 2015 terdapat 202 pasien DBD derajat I- II, dan 136 pasien SSD. Dari 338 kasus dieksklusi 38 kasus karena rekam medis yang tidak lengkap. Kami mengikutsertakan 264 pasien ke dalam penelitian yang terdiri dari 176 pasien DBD derajat I-II (non syok) dan 88 pasien SSD (Gambar 1). Karakteristik dasar kedua kelompok tertera pada Tabel 1.

Berdasarkan hasil analisis bivariat dengan analisis regresi logistik, variabel umur mempunyai nilai $p>0,2$ sehingga tidak dimasukkan dalam analisis multivariat. Berdasarkan analisis multivariat dengan regresi logistik didapatkan status nutrisi (OR=2,29; IK95\%:1,24$4,22)$ dan jenis kelamin (OR=1,84; IK95\%:1,08-3,14) 


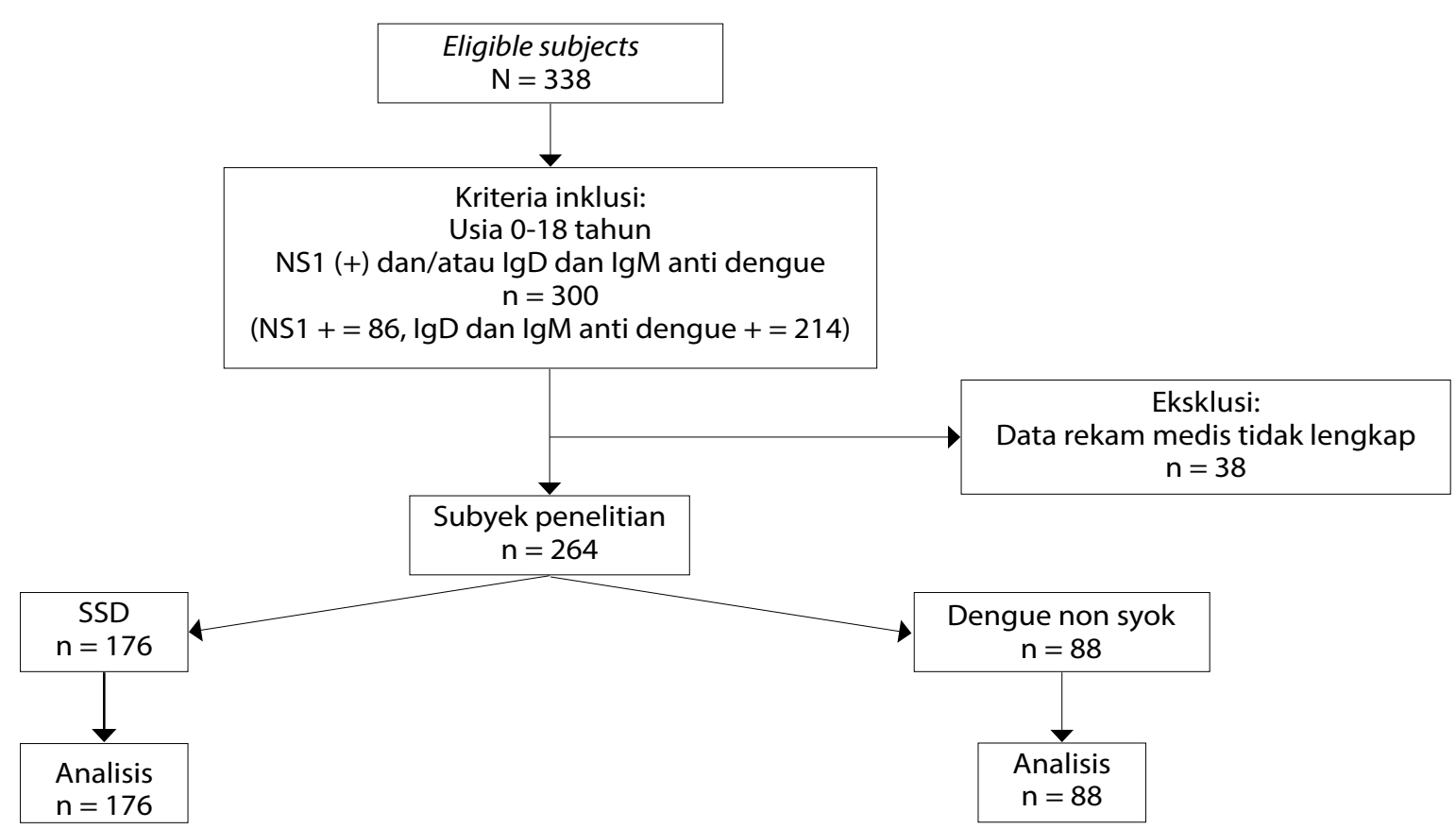

Gambar 1. Alur penelitian

Tabel 1. Karakteristik dasar subjek penelitian

\begin{tabular}{|c|c|c|c|}
\hline Variabel & Kasus/SSD n $=88$ & Kontrol/non syok $\mathrm{n}=176$ & Total $n=264$ \\
\hline \multicolumn{4}{|c|}{ Jenis kelamin, $\mathrm{n}(\%)$} \\
\hline Laki-laki & $44(50)$ & $110(62,5)$ & $154(58,3)$ \\
\hline Perempuan & $44(50)$ & $66(37,5)$ & $110(41,7)$ \\
\hline \multicolumn{4}{|c|}{ Umur, tahun,n(\%) } \\
\hline$<5$ & $28(31,8)$ & $66(38,6)$ & $96(36,4)$ \\
\hline$\geq 5$ & $60(68,2)$ & $108(61,4)$ & $168(63,6)$ \\
\hline \multicolumn{4}{|c|}{ Status nutrisi*, n(\%) } \\
\hline Tidak berisiko & $61(69,3)$ & $145(82,4)$ & $206(78,0)$ \\
\hline Berisiko & $27(30,7)$ & $31(17,6)$ & $58(22,0)$ \\
\hline \multicolumn{4}{|c|}{ Tipe infeksi,n(\%) } \\
\hline Primer & $13(14,8)$ & $33(18,7)$ & $46(17,5)$ \\
\hline Sekunder & $73(82,9)$ & $95(54,0)$ & $168(63,6)$ \\
\hline Missing data & $2(2,3)$ & $48(27,3)$ & $50(18,9)$ \\
\hline \multicolumn{4}{|c|}{ Hemokonsentrasi, $\mathrm{n}(\%)$} \\
\hline$\leq 25 \%$ & $27(30,7)$ & $103(58,5)$ & $130(49,2)$ \\
\hline$>25 \%$ & $61(69,3)$ & $73(41,5)$ & $134(50,8)$ \\
\hline \multicolumn{4}{|c|}{ Jumlah trombosit $(/ \mu \mathrm{L})$} \\
\hline$\geq 20.000$ & $36(40,9)$ & $122(69,3)$ & $158(59,8)$ \\
\hline$<20.000$ & $52(59,1)$ & $54(30,7)$ & $106(40,2)$ \\
\hline
\end{tabular}

${ }^{*}$ Tidak berisiko: $\mathrm{BB} / \mathrm{TB} \leq 2 \mathrm{SD}, \mathrm{BMI} / \mathrm{U} \leq 1 \mathrm{SD}$, Berisiko: $\mathrm{BB} / \mathrm{TB} \leq 2 \mathrm{SD}, \mathrm{BMI} / \mathrm{U} \leq 1 \mathrm{SD}$ 
Sarah Buntubatu dkk: Status nutrisi sebagai faktor risiko sindrom syok dengue

Tabel 2. Analisis univariat \& multivariat faktor yang berpengaruh terhadap SSD

\begin{tabular}{|c|c|c|c|c|c|}
\hline \multirow{2}{*}{ Variabel } & \multicolumn{2}{|c|}{ Univariat } & \multirow{2}{*}{ Nilai $\mathrm{p}$} & \multicolumn{2}{|c|}{ Multivariat* } \\
\hline & OR & IK95\% & & OR & IK95\% \\
\hline Umur $\geq 5$ tahun & 1,35 & $0,78-2,32$ & 0,28 & - & - \\
\hline Perempuan & 1,67 & $0,99-2,80$ & 0,02 & 1,84 & $1,08-3,14$ \\
\hline Overweight/obesitas & 2,07 & $1,14-3,76$ & 0,01 & 2,29 & $1,24-4,22$ \\
\hline
\end{tabular}

*Analisis regresi logistik biner

Tabel 3. Analisis stratifikasi status nutrisi terhadap SSD berdasarkan status imun anti-dengue, hemokonsentrasi, dan jumlah trombosit

\begin{tabular}{|c|c|c|c|c|c|c|}
\hline \multirow[t]{2}{*}{ Variabel } & \multirow{2}{*}{$\begin{array}{l}\text { Status nutrisi } \\
\text { SSD } \mathrm{n}(\%)\end{array}$} & \multicolumn{2}{|c|}{ Status dengue } & \multirow[t]{2}{*}{$\mathrm{p}$} & \multirow[t]{2}{*}{ OR } & \multirow[t]{2}{*}{ IK95\% } \\
\hline & & Non SSD n $(\%$ & & & & \\
\hline \multicolumn{7}{|c|}{ Status imun anti dengue } \\
\hline \multirow[t]{2}{*}{ Infeksi primer } & Tidak berisiko & $12(92,3)$ & $28(84,8)$ & \multirow{4}{*}{0,06} & 0,47 & $0,05-4,43$ \\
\hline & Berisiko & $1(7,7)$ & $5(15,2)$ & & & \\
\hline \multirow[t]{2}{*}{ Infeksi sekunder } & Tidak berisiko & $49(67,1)$ & $77(81,1)$ & & 2,09 & $1,03-4,25$ \\
\hline & Berisiko & $24(32,9)$ & $18(18,9)$ & & & \\
\hline \multicolumn{7}{|l|}{ Hemokonsentrasi } \\
\hline \multirow[t]{2}{*}{$\leq 25 \%$} & Tidak berisiko & $22(81,5)$ & $88(85,4)$ & \multirow{4}{*}{0,02} & 1,33 & $0,44-4,06$ \\
\hline & Berisiko & $5(18,5)$ & $15(14,6)$ & & & \\
\hline \multirow[t]{2}{*}{$>25 \%$} & Tidak berisiko & $39(63,9)$ & $57(78,1)$ & & 2,01 & $0,94-4,31$ \\
\hline & Berisiko & $22(36,1)$ & $16(21,9)$ & & & \\
\hline \multicolumn{7}{|c|}{ Angka trombosit $(/ \mu \mathrm{L})$} \\
\hline \multirow[t]{2}{*}{$\geq 20.000$} & Tidak berisiko & $26(72,2)$ & $98(80,3)$ & \multirow{4}{*}{0,02} & 1,57 & $0,67-3,69$ \\
\hline & Berisiko & $10(27,8)$ & $24(19,7)$ & & & \\
\hline \multirow[t]{2}{*}{$<20.000$} & Tidak berisiko & $35(67,3)$ & $47(87,0)$ & & 3,26 & $1,22-8,72$ \\
\hline & Berisiko & $17(32,7)$ & $7(13,0)$ & & & \\
\hline
\end{tabular}

*Tidak berisiko: $\mathrm{BB} / \mathrm{TB} \leq 2 \mathrm{SD}, \mathrm{BMI} / \mathrm{U} \leq 1 \mathrm{SD}$, Berisiko: $\mathrm{BB} / \mathrm{TB} \leq 2 \mathrm{SD}, \mathrm{BMI} / \mathrm{U} \leq 1 \mathrm{SD}$

merupakan variabel yang berpengaruh dan sebagai faktor risiko terjadinya SSD. Jenis kelamin bukan sebagai confounder karena perubahan dari analisis multivariat nilai OR $<10 \%(9,6 \%)$ seperti tertera pada Tabel 2.

Pada Tabel 3, dengan analisis stratifikasi status nutrisi terhadap SSD berdasarkan variabel yang dianggap sebagai modifier (status imun anti dengue, hemokonsentrasi, dan angka trombosit) didapatkan nilai OR pada tiap strata berbeda. Dengan demikian, berarti ketiganya merupakan modifier yang memengaruhi hubungan status nutrisi dengan kejadian SSD. Risiko SSD pada pasien dengan status nutrisi berisiko meningkat secara bermakna pada kelompok dengan angka trombosit $<20.000 / \mathrm{uL}$ $(\mathrm{OR}=3,26$; IK95\%:1,22-8,72), sedangkan peningkatan hematokrit $>25 \%$ tidak bermakna. Status imun anti-dengue tidak mempunyai hubungan yang bermakna dengan kejadian SSD karena mempunyai nilai $\mathrm{p}>0,05$.

\section{Pembahasan}

Kami mendapatkan bahwa perempuan 1,8 kali berisiko mengalami SSD dibanding lelaki. Hal tersebut dimungkinkan karena terdapat perbedaan secara imunologis antara anak perempuan dan lelaki. Perempuan memiliki respon imun yang lebih kuat sehingga memproduksi sitokin yang lebih besar dan permeabilitas kapiler yang lebih tinggi sehingga lebih cepat mengalami syok. ${ }^{18,19}$ Hasil penelitian kami sama dengan penelitian di Semarang dan Vietnam. ${ }^{20,21}$ Pada suatu penelitian, variabel dianggap sebagai confounder 
apabila perbedaan OR pada analisis bivariat dengan OR pada analisis multivariat $>10 \%\left(\mathrm{OR}_{\text {stratifikas }}\right)$, pada penelitian ini jenis kelamin bukan sebagai confounder karena dari analisis multivariat perbedaan $\mathrm{OR}_{\text {stratifikasi }}$ $9,6 \%$.

Penelitian kami menunjukkan 68,2\% kasus SSD terjadi pada usia $\geq 5$ tahun, tetapi tidak mempunyai hubungan yang bermakna dengan SSD. Hasil tersebut sesuai dengan penelitian di Vietnam, dan beberapa penelitian di Indonesia. ${ }^{910,22-24}$ Kejadian DBD lebih sering pada usia $>5$ tahun mungkin disebabkan karena mikrovaskular dan permeabilitas yang lebih besar pada usia $>5$ tahun. Peningkatan permeabilitas pembuluh darah mungkin disebabkan oleh beberapa faktor, yaitu vaskular dan perembesan plasma yang lebih besar. ${ }^{25}$ Penelitian menunjukkan bahwa sel endotel vaskular dapat menjadi target infeksi virus dengue. Sel endotel dikenal berperan penting dalam mengatur permeabilitas pembuluh, serta mempertahankan hemostasis dan juga berperan dalam produksi sitokin. Virus dengue dapat menginduksi produksi interleukin (IL)-6 dan IL-8 oleh sel endotel yang berkontribusi pada patogenesis DBD. Semakin banyak sel yang terinfeksi, lebih banyak interleukin dihasilkan yang akan meningkatkan permeabilitas kapiler sehingga meningkatkan risiko SSD. ${ }^{26}$

Pada penelitian kami, anak dengan overweight dan obes berisiko 2 kali lebih besar mengalami SSD dibandingkan anak gizi baik atau malnutrisi, seperti pada beberapa penelitian sebelumnya, ${ }^{8-10}$ tetapi berbeda dengan beberapa penelitian lain. ${ }^{27,11-13}$ Hubungan status gizi seseorang erat kaitannya dengan respon imun tubuh. Pada individu yang overweight atau obes terjadi penumpukan jaringan lemak akibat peningkatan jumlah dan besar sel adiposit. Di antara jaringan lemak, sel adiposit jaringan lemak putih yang mensekresikan dan melepaskan sitokin pro-inflamasi tumour necrosis factor $\alpha$ (TNF $\alpha)$ dan beberapa interleukin (IL) yaitu IL-1 $\beta$, IL-6, dan IL-8. Pada obesitas akan terjadi peningkatan ekspresi TNF $\alpha$ dan IL-6 sedangkan pada SSD terjadi produksi TNF $\alpha$, IL1, IL-6, dan IL-8. Peningkatan ekspresi TNF $\alpha$ dan IL-6 ini berperan dalam menyebabkan syok sehingga obesitas lebih berisiko mengalami SSD. ${ }^{5-7}$

Sebuah penelitian mendapatkan bahwa kejadian infeksi sekunder terjadi pada $90,5 \%$ pada SSD dan $88,6 \%$ pada DHF. Pada kejadian luar biasa (KLB) tahun 2004 di Jakarta, infeksi sekunder terjadi 82,5\%. Pada penelitian kami, infeksi sekunder terjadi pada
63,6\% kasus, kejadian infeksi sekunder pada pasien SSD adalah $82,9 \% \cdot{ }^{5,8,28}$ Hipotesis reaksi sekunder heterologus mengatakan bahwa penularan pertama virus dengue (infeksi primer) akan menimbulkan reaksi imunitas. Selanjutnya, bila mendapat infeksi ulang (infeksi sekunder) virus dengue dengan serotipe berbeda, dalam beberapa hari akan mengakibatkan proliferasi limfosit dengan menghasilkan immunoglobulin $\mathrm{G}$ (IgG) antivirus dengue dan mengakibatkan DBD. ${ }^{29}$

Hemokonsentrasi merupakan penanda kebocoran plasma. Nilai hematokrit dipengaruhi oleh perdarahan dan pemberian cairan. Perdarahan dapat menyebabkan penurunan hematokrit, sedangkan dehidrasi dan kebocoran plasma dapat menyebabkan peningkatan hematokrit, gangguan perfusi jaringan, dan kemudian syok. Pada penelitian kami, hemokonsentrasi mempunyai hubungan yang bermakna dengan derajat infeksi dengue. Dari hasil analisis stratifikasi pasien dengan status nutrisi overweight atau obes yang mengalami peningkatan nilai hematokrit $>25 \%$ mempunyai risiko 2 kali lebih besar untuk terjadi syok dibanding pasien dengan status nutrisi normal atau malnutrisi. Peningkatan hematokrit $>25 \%$ sebagai modifier tidak bermakna. Para peneliti melaporkan peningkatan hematokrit $>25 \%$ berisiko 2 kali lebih besar untuk SSD, kenaikan hematokrit $>25 \%$ sebagai prediktor terjadinya SSD, dan hemokonsentrasi $>22 \%$ menunjukkan gejala syok yang lebih awal. ${ }^{27,13,30}$

Jumlah trombosit yang rendah mungkin menyebabkan perdarahan sehingga mempercepat terjadinya syok. Trombosit adalah sel yang mengandung semua jenis mediator. Kerusakan endotel menyebabkan agregasi trombosit dan trombosit teraktivasi akan melepaskan histaminelike sub-stance dan 5-hydroxytryptamine yang dapat meningkatkan permeabilitas pembuluh darah. ${ }^{31}$ Hasil penelitian kami menunjukkan angka trombosit berhubungan dengan kejadian SSD. Dari analisis stratifikasi, pasien dengan jumlah trombosit $<20.000 /$ $\mathrm{uL}$ dan status nutrisi overweight atau obesitas mempunyai risiko 3,3 kali lebih besar menjadi SSD dibandingkan pasien dengan jumlah trombosit $<20.00 /$ $\mathrm{uL}$ dengan status nutrisi normal atau malnutrisi. Dengan melihat $\mathrm{OR}_{\text {stratifikasi }}$ antara status nutrisi berisiko dan status nutrisi tidak berisiko terdapat perbedaan antara nilai $\mathrm{OR}_{\text {berisiko }}$ dengan $\mathrm{OR}_{\text {tidak berisiko, }}$ yang berarti angka trombosit merupakan modifier. Hasil penelitian kami mendukung penelitian sebelumnya di Makassar yang melaporkan bahwa pasien dengan SSD sering 
memiliki angka trombosit $<20.000 /$ uL dibandingkan dengan pasien DBD non syok, sedangkan penelitian lain melaporkan bahwa angka trombosit <20.000/ uL tidak berhubungan dengan keparahan infeksi dengue. Peneliti lain melaporkan perdarahan berat yang dihubungkan dengan angka trombosit tidak meningkatkan risiko terjadinya SSD. ${ }^{9}, 14,31,32$

Penelitian kami memiliki kekurangan karena data yang diambil adalah data sekunder dan tidak semua pasien dilakukan pemeriksaan serologis. Penelitian kami juga tidak memperhitungkan ada tidaknya perdarahan pada pasien. Perlu penelitian lanjutan secara kohort sehingga bisa didapatkan data yang lengkap.

\section{Kesimpulan}

Anak DBD yang overweight atau obes mempunyai risiko 2,3 kali mengalami syok dibandingkan bukan overweight atau obes, perempuan mempunyai risiko 1,8 kali mengalami syok dibanding laki-laki. Angka trombosit merupakan modifier.

\section{Daftar pustaka}

1. Karyanti MR, Hadinegoro SR. Perubahan epidemiologi demam berdarah dengue di Indonesia. Sari Pediatri 2009; 10:424-32.

2. Ditjen PP \& PL Kementerian Kesehatan Republik Indonesia. Profil Kesehatan Indonesia tahun 2013. Kementerian Kesehatan Republik Indonesia; 2014.

3. Harun SR. Tatalaksana demam dengue/demam berdarah dengue pada anak. Dalam: Rezeki, S., penyunting. Demam berdarah dengue naskah lengkap pelatihan bagi dokter spesialis anak dan dokter spesialis penyakit dalam. Jakarta: Balai Penerbit FK UI; 2000.h.83-137.

4. Halstead SB. Dengue fever and dengue hemorrhagic fever. Dalam: Behrman RE, Kliegman RM, Jenson HB, penyunting. Nelson Texbook of Pediatrics. Edisi ke-17. Philadelphia: W.B Saunders Company; 2004. h.1092

5. Sutaryo. Dengue. Yogyakarta: Medika Fakultas Kedokteran Universitas Gadjah Mada; 2004.

6. Trayhurn P, Wood LS. Signalling role of adiposetissue: adipokines and inflammation in obesity. Biochemical Society Transactions 2005;33:078-81.

7. Coppack SW. Pro-inflammatory cytokines and adipose tissue. Proc Nutr Soc 2001;60:349-56.
8. Pichainarong N, Mongkalangoon N, Katayanarooj S, Chaveepojnkamjorn W. Relationship between body size and severity of Demam berdarah dengue among children aged 0-14 years. Southlast Asian J Trop Med Public Health 2006;3:283-8.

9. Junia J, Garna H, Setiabudi D. Clinical risk factors for sindrom syok dengue in children. Paediatr Indones 2007;47:7-11.

10. Saniathi E, Arhana BNP, Suandi IKG, Sidiartha IGL. Obesitas sebagai faktor risiko sindrom syok dengue. Sari Pediatri 2009; 11:238-43.

11. Maron GM, Clara AW, Diddle JW, Pleités EB, Miller L, MacDonald G, dkk. Association between nutritional status and severity of dengue infection in children in El Salvador. Am J Trop Med Hyg 2010;82:324-9.

12. Ganda IJ, Bombang H. Morbiditas dan mortalitas sindrom syok dengue di Pediatric Intensive Care Unit (PICU) Bagian Ilmu Kesehatan Anak Rumah Sakit Dr. Wahidin Sudirohosodo Makassar Januari 1998-Desember 2005. J Med Nus 2005;26:244-50.

13. Widiyati MMT, Laksanawati IS, Prawirohartono EP. Obesity as a risk factor for sindrom syok dengue in children. Paediatr Indones 2013;53:187-92.

14. World Health Organization. Comprehensive guidelines for prevention and control of dengue and dengue haemorrhagic fever, revised and expanded edition. Geneva: WHO;2011.

15. Lemeshow S,Hosmer Jr DW, Klar J, Lwanga SK. Adequacy of sample size in health studies. World health organization. England. Published by John Wiley \& Sons Ltd 1990;7:36-8.

16. World Health Organization. WHO child growth standards and the identification of severe acute malnutrition in infants and children. 2007. Diunduh pada 20 Agustus 2016. Didapat dari: http://www.who.int/nutgrowthdb/about/introduction/en/ print.html.

17. World Health Organization. Growth reference data for 5-19 years. 2007. Diunduh pada 20 Agustus 2016. Didapat dari: http://www. who.int/nutgrowthdblabout/introduction/en/print.html.

18. Whitehorn J, Simmons CP. The pathogenesis of dengue. Vaccine 2011;29:7221-8.

19. Anders KL, Nguyet NM, Chau NVV, Hung NY, Thuy TT, Lien LB. Epidemiological factors associated with sindrom syok dengue and mortality in hospitalized dengue patiens in Ho Chi Minh City, Vietnam. Am J Trop Med Hyg 2011;84:127-34.

20. Suharti C, Setiati TE, Gorp ECMV, Djokomoeljanto RJ, Trastotenojo MS, Meer JWMV. Risk factors for mortality in sindrom syok dengue. M Med Indones 2009;43:213-9.

21. Phuong CXT, Nhan NT, Kneen R, Thuy TT, Solomon T, Stepniewska K, dkk. Clinical diagnosis and assessment of severity of confirmed dengue infections in Vietnmese children: Is the world health organization classification system helpful?. Am J Med Hyg 2004;7:172-9. 
22. Bunnag T, Kalayanarooj S. Sindrom syok dengue at the emergency room of Queen Sirikit national Institute of Child Health, Bangkok, Thailand. J Med Assoc Thai 2011;94:S57-S63.

23. Ganda IJ, Bombang H. Morbiditas dan mortalitas sindrom syok dengue di Pediatric Intensive Care Unit (PICU) Bagian Ilmu Kesehatan Anak Rumah Sakit Dr. Wahidin Sudirohosodo Makassar Januari 1998-Desember 2005. J Med Nus 2005;26:244-50.

24. World Health Organization. Dengue, dengue haemorrhagic fever and sindrom syok dengue in the contex of the integrated management of childhood illness. Department of Child and Adolescent Health and Development. WHO;2005.

25. Guzman MG, Kouri G, Bravo J, Valdes L, Vazquez S, Halstead SB. Effect of age on outcome of secondary dengue infections. Int J Infect Dis 2002;6:118-24.

26. Huang YH, Lei HY, Liu HS, Lin YS, Yeh TM. Dengue virus infects human endothelial cells and induces IL-6 and IL-8 production. Am J Trop Med Hyg 2000;63:71-5.
27. Tantracheewathorn T, Tantracheewathorn S. Risk factors of sindrom syok dengue in children. J Med Assoc Thai 2007;90:272-7.

28. Soegijanto S. Aspek imunologi penyakit demam berdarah, dalam Demam berdarah dengue Edisi 2. Surabaya: Airlangga University Press. 2006.h.41-59.

29. Recker M, Blyuss KB, Simmons CP, Hien TT, Wills B, Farrar $\mathrm{J}$, dkk. Immunological serotype interactions and their effect on the epidemiological pattern of dengue. Proc R Soc B 2009;276:2541-8.

30. Chuansumrit A, Puripokal C, Butthep P, Wongtiraporn W, Sasanakul W, Tangnararatchakit K, dkk. Laboratory predictors of sindrom syok dengue during the febrile stage. Southeast Asian J Trop Med Public Health 2010;41:326-32.

31. Dewi R, Tumbelaka AR, Syarif DR. Clinical features of dengue hemorrhagic fever and risk factors of shock event. Paediatr Indones 2006;46:144-8.

32. Sutaryo. Patogenesis dan patofisiologi demam berdarah dengue. Cerm Dunia Kedokter (edisi khusus) 1992;81:35-8 